\title{
Bioprospecting
}

\section{of exopolysaccharide-producing bacteria from different natural ecosystems for biopolymer synthesis from vinasse}

\author{
Valeria Ventorino ${ }^{1}$, Barbara Nicolaus², Paola Di Donato ${ }^{2,3}$, Giorgia Pagliano ${ }^{1}$, Annarita Poli²,
} Alessandro Robertiello ${ }^{1}$, Valeria lavarone ${ }^{1}$ and Olimpia Pepe ${ }^{1 *}$

\begin{abstract}
Background: Exopolysaccharides (EPSs) belong to a family of organic thickeners or alternative hydrocolloids of microbial origin. Because the chemical structure offers beneficial bioactive functions, biocompatibility and biodegradability, EPSs are used in the chemical, food, pharmaceutical, cosmetics, and packaging industries as well as in agriculture and medicine. In this study, new bacterial strains were selected on the basis of their ability to synthesize EPS from substrate containing vinasse as a nutrient source to identify the best candidate for bio-based polymer production.

Results: Among the 99 newly identified bacterial strains isolated from different natural ecosystem, the strain Azotobacter chroococcum 76A was selected as the best biopolymer producer since it synthesized the highest concentration of EPS in all media containing vinasse. The maximum EPS concentration $(44.6 \pm 0.63 \mathrm{mg} / 50 \mathrm{~mL}$ ) was observed at $24 \mathrm{~h}$, corresponding to its sub-stationary growth phase $\left(7 \times 10^{8} \pm 0.29 \mathrm{CFU} / \mathrm{mL}\right)$. Chemical characterization of the EPS produced showed that carbohydrates representing the principal component, followed by uronic acids and proteins. Interestingly, comparing the IR spectrum of the EPS with alginate by FTIR-ATR analysis revealed an overlap of a peak identified as guluronic acid, a component of alginate.

Conclusions: The potential biotechnological capacity of A. chroococcum 76A to synthetize biopolymer from vinasse, inexpensive starting materials, represents a possible alternative to expensive disposal of agri-food waste through its transformation into high value-added products.
\end{abstract}

Keywords: Bacterial selection, Azotobacter chroococcum, Agri-food waste, Vinasse, Exopolysaccharides, Biopolymers

\section{Background}

Exopolysaccharides (EPSs) are useful for an extensive range of industrial applications. They are renewable sources of hydrocolloids, which are used in the food, pharmaceutical, agricultural, cosmetics and medical as well as in the chemical industries, where they replace petroleum-based polymers [1-4].

\footnotetext{
*Correspondence: olipepe@unina.it

${ }^{1}$ Department of Agricultural Sciences, University of Naples Federico II, Via Università 100, 80055 Portici, NA, Italy

Full list of author information is available at the end of the article
}

EPSs are produced by bacteria, algae and, in smaller amounts, by yeasts and molds [5-7] to protect the cell from unfavorable, limiting or toxic conditions [8], thereby improving microbial competition in different environments [9]. A great variety of microbial EPSs are known to be synthesized by different microbial genera, such as dextran by Leuconostoc and Lactobacillus, gellan by Sphingomonas and Aureomonas, xanthan by Xanthomonas, alginates by Pseudomonas and Azotobacter, succinoglycan by Alcaligenes and Rhizobium, hyaluronic acid by Streptococcus, schizophyllan by Schizophylum, levan by Alcaligenes and Zymomonas, pullulan by Aureobasidium, 
cellulose by Acetobacter, chitosan by Mucorales, galactoglucopolysaccharides and biosurfactant by Achromobacter, Agrobacterium, Pseudomonas, Rhizobium and Zooglea, scleroglucan by Sclerotium, and welan by Alcaligenes [9-11]. Due to the wide diversity of structures and functional properties, there is an increasing interest in EPSs synthesized by microorganisms [12-14]. In fact, microbial EPS could represent a good alternative to EPS obtained from plant, animal and seaweed, because they can be produced under controlled conditions [15-17]. However, bacterial EPS represents only a small fraction of the current biopolymer market because of their high cost of production, which is mostly related to substrate cost and recovery $[10,18]$. Therefore, the use of cheaper substrates, such as agricultural byproducts and waste materials, could represent a good approach to reduce the production costs for EPS biosynthesis.

Currently, the management and disposal of vinasse, a recalcitrant waste of the sugar-ethanol industry, has emerged as a priority from an environment perspective due to its polluting load, especially Biological Oxygen Demand (BOD) [19, 20]. Agri-food wastes are additional cheap, sustainable and attractive substrate for the production of biopolymers or other high value-added products [21]. Many studies have assessed the recycling and the potential use of agri-food wastes and byproducts or dedicated energy crops for producing polyhydroxyalkanoate (PHA) [22, 23], succinic acid [24-27], biofuels and biogas $[19,28-32]$ as well as biological hydrogen and volatile fatty acids [33, 34]. Natural environments represent important sources of microbial strains that exert interesting enzymatic activities for biotechnological applications [35].

The aim of this study was to select bacterial strains on the basis of their ability to synthesize EPS from substrate containing vinasse as a nutrient source and identify the best candidate for bio-based polymer production.

\section{Methods}

\section{Composition of sugarcane vinasse}

Sugarcane vinasse was kindly provided by Agriges S.r.l. (San Salvatore Telesino, Benevento, Italy).

The chemical composition of sugarcane vinasse was determined by high-performance liquid chromatography (HPLC) (Refractive index detector 133; Gilson system; pump 307, column Metacarb 67 h, Varian, with a flow of $0.4 \mathrm{~mL} / \mathrm{min}$ of $0.01 \mathrm{~N} \mathrm{H}_{2} \mathrm{SO}_{4}$ ). Chemical oxygen demand (COD) was estimated with an ECO08 thermoreactor (Velp Scientifica, Usmate, Monza Brianza, Italy) and a PF-3 photometer (Velp Scientifica) using NANOCOLOR ${ }^{\circledR}$ kit. BOD $_{5}$ was measured with a BOD Sensor System 6 (Velp Scientifica) according to manufacturer's instructions.

\section{Bacterial strains and EPS production on solid media}

Ninety-nine bacterial strains isolated from different natural ecosystems (lignocellulosic biomass, soil, compost, bakery products) were used in this study: 27 endocellulolytic bacteria, 14 exo-cellulolytic bacteria [36], 3 free-living $\mathrm{N}_{2}$-fixing bacteria belonging to Azotobacter chroococcum species [37], 42 Bacillus spp. [38], 3 lactic acid bacteria [39] and 10 Pseudomonas spp. [37, 40]. To carry out a preliminary selection, all bacterial strains were first refreshed in a specific nutrient media and incubated for $24-48 \mathrm{~h}$ at $30^{\circ} \mathrm{C}$. For EPS detection, all strains were streaked on Salts Agar Base medium (SAB) (composition per liter: $0.15 \mathrm{~g} \mathrm{KH}_{2} \mathrm{PO}_{4}, 0.5 \mathrm{~g} \mathrm{~K}_{2} \mathrm{HPO}_{4}, 0.2 \mathrm{~g} \mathrm{MgSO}_{4}$, $0.1 \mathrm{~g} \mathrm{NaCl}, 18 \mathrm{~g}$ Agar, $\mathrm{pH}$ 6.8-7) to which mannitol (1\%) or sucrose $(5 \%)$ was added as carbon sources with yeast extract $(0.4 \%)$. After incubation for $48 \mathrm{~h}$ at $30{ }^{\circ} \mathrm{C}$ the bacterial strains growth as ropy colonies (data not shown) were further assayed for their ability to produce EPS under specific nutritional conditions. Specifically, the selected strains were streaked onto SAB medium containing a mixture of different concentrations of sucrose $(0,0.5$, $1,1.5,2$ or $5 \%)$, sugarcane vinasse $(0,1,5$ or $10 \%)$ and with yeast extract $(0.4 \%)$. Inoculated plates were examined after $48 \mathrm{~h}$ of incubation at $30{ }^{\circ} \mathrm{C}$ to detect the presence of ropy colonies due to putative production of EPS.

\section{EPS synthesis by selected Azotobacter chroococcum strains in liquid medium}

On the basis of the capacity to growth and form ropy colonies in the different solid media containing vinasse as carbon source, A. chroococcum 76A, AZ1 and 67B were selected to evaluate their ability to produce EPS in liquid medium. These bacterial strains were precultured in $10 \mathrm{~mL}$ of Yeast Mannitol (YM) broth and incubated for $24-48 \mathrm{~h}$ at $30{ }^{\circ} \mathrm{C}$. After inoculum standardization using a Thoma cell counting chamber (depth $0.02 \mathrm{~mm}$; $1 / 400 \mathrm{~mm}^{2}$; Hawksley, United Kingdom), $1 \mathrm{~mL}$ of each culture was added to achieve viable counts of approximately $2 \times 10^{7}$ cells $/ \mathrm{mL}$ in Salts Broth (SB) containing vinasse (1\%) and sucrose (5\%) as carbon sources. After 24 and $48 \mathrm{~h}$ of incubation at $30^{\circ} \mathrm{C}$, tenfold serial dilutions of the cultures were made in Ringer solution (Oxoid, Milan, Italy) and bacterial cells were enumerated by spreading $100 \mu \mathrm{L}$ of each dilution on YM solid medium plates. EPS was quantified as described by Palomba et al. [16]. Briefly, supernatant containing EPS was precipitated with 2 volumes of chilled $98 \%$ (vol/vol) ethanol and incubated overnight at $4{ }^{\circ} \mathrm{C}$. After centrifugation $(5200 \times g$ for $10 \mathrm{~min}$ at $4{ }^{\circ} \mathrm{C}$ ), the recovered pellets were suspended in $1 \mathrm{~mL}$ of distilled water, freeze-dried and weighed to obtain the amount of EPS, expressed as polymer dry mass (PDM, $\mathrm{mg} / 30 \mathrm{~mL}$ of wet medium). 
Monitoring and characterization of EPS produced by Azotobacter chroococcum 76A Monitoring of microbial growth and EPS production Azotobacter chroococcum 76A was inoculated into $50 \mathrm{~mL}$ of liquid substrate composed of vinasse (1\%) and sucrose (5\%) as carbon sources. Samples were withdrawn immediately after inoculation and after 8, 16, 24, 32 and $48 \mathrm{~h}$ of incubation at $30{ }^{\circ} \mathrm{C}$, to determine bacterial growth and EPS concentration performed as described above.

\section{Chemical characterization of EPS}

After the inoculum standardization, A. chroococcum $76 \mathrm{~A}$ was inoculated in liquid or solid media containing vinasse (1\%) and sucrose (5\%). After $24 \mathrm{~h}$ at $30{ }^{\circ} \mathrm{C}$, the EPS was recovered from liquid cultures as described above or was taken directly from plates (Fig. 1) by repeatedly washing with distilled water until disappearance of the visible ropy patina, after which the EPS was collected in sterile falcon tubes [16]. EPSs obtained from the liquid or solid media were precipitated by ethanol, freeze-dried and then dissolved in hot water, cooled at room temperature and finally dialyzed against water for 3 days (Visking Dialysis Membrane MWCO 12-14 kDa, GmbH, Germany). Next, the EPS samples were freeze-dried again. Gross chemical composition was determined by assaying the contents of total carbohydrates, proteins and uronic acids. The total carbohydrate contents were quantified according to the phenol-sulfuric acid method [41] using a standard curve with glucose. The protein concentrations were determined using a Bradford protein assay kit (BioRad, Milan, Italy) and Bovine Serum Albumin (BSA) as a standard [42]. The total content of uronic acids was determined according to the method described by Blumenkrantz and Ashoe-Hansen [43] using galacturonic acid for calibration. The monosaccharide composition

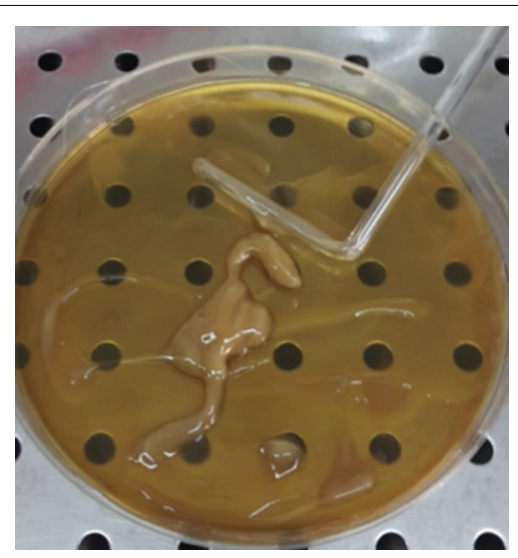

Fig. 1 Collection of EPS produced by Azotobacter chroococcum 76A from solid medium containing vinasse (1\%) and sucrose (5\%) after $24 \mathrm{~h}$ of incubation at $30^{\circ} \mathrm{C}$ of the EPS was determined after acid hydrolysis with $2 \mathrm{~N}$ trifluoroacetic acid (TFA) at $120{ }^{\circ} \mathrm{C}$ for $2 \mathrm{~h}$ using a glucose enzymatic assay [44]. The spectral characterization was performed via Attenuated Total Reflection Fourier Transform Infrared (FTIR-ATR) spectroscopy and by ${ }^{1} \mathrm{H}$ NMR. The infrared spectra of the EPS were recorded at room temperature with a Spectrum 100 FTIR spectrometer (Perkin-Elmer Inc., Norwalk, CT, USA) equipped with a crystal diamond universal ATR sampling accessory. For the ${ }^{1} \mathrm{H}-\mathrm{NMR}$ analysis, the samples were dissolved in $\mathrm{D}_{2} \mathrm{O}(5 \mathrm{mg} / \mathrm{mL})$ and spectra were recorded on a Bruker AMX-600 MHz ${ }^{1} \mathrm{H}-\mathrm{NMR}$ at $40{ }^{\circ} \mathrm{C}$ [45].

\section{Statistical analyses}

One-way ANOVA followed by Tukey's HSD post hoc test for the pairwise comparison of means (at $P<0.05)$ were used to assess the differences in EPS production. Statistical analyses were performed using the SPSS 21.0 statistical software package (SAS Inc., Cary, NC).

\section{Results and discussion}

Screening of EPS-producing bacterial strains on solid media containing sugarcane vinasse

Ninety-nine bacterial strains previously isolated from different matrices were tested to identify high EPSproducing strains. The preliminary screening allowed the selection of 14 strains able to grow and form ropy colonies on solid media containing mannitol or sucrose with or without yeast extract (0.4\%). Interesting was to observe that the natural soil ecosystem showed the highest occurrence of EPS-producing bacteria (38.5\%, Table 1). Hence, studies of the occurrence of bacteria with structural elements such as capsules or polysaccharides that have physiological functions in different natural ecosystems are important to obtain better knowledge of the origin and evolution of bacteria. Moreover, the higher occurrence of EPS production by bacterial strains isolated from soil or lignocellulosic biomass have an ecological meaning since these traits may be used by naturally occurring bacteria to survive

Table 1 Percentage of bacterial strains able to growth and secrete EPS on solid media containing a mixture of different concentrations of mannitol (1\%) or sucrose (5\%) as carbon sources

\begin{tabular}{lll}
\hline Source & $\begin{array}{l}\text { Number of tested } \\
\text { strains }\end{array}$ & $\begin{array}{l}\text { EPS- } \\
\text { producing } \\
\text { strains (\%) }\end{array}$ \\
\hline Soil & 13 & 38.5 \\
Lignocellulosic biomass & 41 & 14.6 \\
Bakery products & 45 & 6.7 \\
\hline
\end{tabular}


and grow in specific habitats enhancing their environmental survival [36, 37, 46].

EPS-producing bacterial strains from the preliminary screening, were further tested on media containing sugarcane vinasse composed of $30.33 \mathrm{~g} / \mathrm{L}$ of lactic acid, $29.6 \mathrm{~g} / \mathrm{L}$ of succinic acid, $12.63 \mathrm{~g} / \mathrm{L}$ of acetic acid, $6.77 \mathrm{~g} / \mathrm{L}$ of fructose, and $3.26 \mathrm{~g} / \mathrm{L}$ of ethanol and had a $\mathrm{pH}$ of approximately 6.4, COD and BOD values of $556 \mathrm{~g} / \mathrm{L}$ and $216 \mathrm{~g} / \mathrm{L}$, respectively. In particular, Xanthomonas campestris CP81 and SBP63, Sphingobacterium multivorum CA77, Labedella gwakjiensis CP710, Aurantimonas altamirensis SBP73 and Curtobacterium flaccumfaciens CP77b isolated from lignocellulosic biomass, A. chroococcum 76A, A. chroococcum 67B, A. chroococcum AZ1, Pseudomonas gessardii SA33A and Pseudomonas sp. SA33B isolated from soil and Leuconostoc lactis 95A, Leuconostoc lactis 69B and Lactobacillus curvatus 69B2 isolated from bakery products, were screened on solid media with different concentrations of sugarcane vinasse and sucrose, as carbon sources. Increasing the vinasse concentration resulted in a reduction of bacterial strains able to grow and produce EPS on the solid media that were tested (Table 2). However, more bacterial strains were able to grow and synthetize EPS from vinasse when sucrose was added to the medium. In fact, by increasing the concentration of sucrose from 0.5 to $2 \%$, the number of bacterial strains that exhibited ropy colonies increased from 7 to 13 . In contrast, a higher amount of sugarcane vinasse seemed to result in an inhibitory effect, since only four strains exhibited EPS production on solid media containing $5 \%$ of vinasse. Increasing the concentration of vinasse up to $10 \%$ resulted in the inhibition of bacterial growth (Table 2). The presence of specific toxic compounds such as furfural, HMF, $p$-hydroxybenzoic aldehyde and vaniline, are known to have inhibitory effects on microbial metabolism, limiting the efficient conversion of fermentable sugars into biochemicals $[25,26,47]$.

Similarly, Vermani et al. [48] reported that high concentrations of glucose and lactose in culture media exerted inhibitory effects on the microbial growth and EPS synthesis in Azotobacter strains.

Among the fourteen bacterial strains tested, only $A$. chroococcum 76A, A. chroococcum 67B and A. chroococcum AZ1 were able to produce EPS on media containing $1 \%$ or $5 \%$ of sugarcane vinasse without added sucrose or yeast extract as additional nutritional sources.

\section{Growth and EPS production by A. chroococcum strains in liquid media containing sugarcane vinasse}

Based on the results obtained using the solid media, three selected Azotobacter strains were tested in liquid media containing vinasse $(1 \%)$ with or without sucrose $(2 \%$ or
Table 2 Screening of EPS-producing bacterial strains on solid media composed by Salts Agar Base (SAB) with nutrient mixtures of vinasse $(1,5$ or $10 \%)$ and sucrose $(0,0.5,1,1.5,2$ or $5 \%)$ as carbon sources with and without yeast extract $(0.4 \%)$

\begin{tabular}{|c|c|c|c|}
\hline \multicolumn{3}{|c|}{ Composition of nutrient mixtures added to $S A B$} & \multirow{2}{*}{$\begin{array}{l}\text { Number } \\
\text { of positive } \\
\text { strains }^{\mathrm{a}}\end{array}$} \\
\hline Vinasse (mL/L) & Sucrose $(g / L)$ & $\begin{array}{l}\text { Yeast extract } \\
\text { (g/L) }\end{array}$ & \\
\hline 10 & 0 & 0 & 3 \\
\hline 10 & 0 & 4 & 3 \\
\hline 10 & 5 & 0 & 7 \\
\hline 10 & 10 & 0 & 7 \\
\hline 10 & 15 & 0 & 8 \\
\hline 10 & 20 & 0 & 10 \\
\hline 10 & 50 & 0 & 13 \\
\hline 50 & 0 & 0 & 3 \\
\hline 50 & 0 & 4 & 3 \\
\hline 50 & 5 & 0 & 3 \\
\hline 50 & 10 & 0 & 3 \\
\hline 50 & 15 & 0 & 3 \\
\hline 50 & 20 & 0 & 4 \\
\hline 50 & 50 & 0 & 6 \\
\hline 100 & 0 & 0 & 0 \\
\hline 100 & 0 & 4 & 0 \\
\hline 100 & 5 & 0 & 0 \\
\hline 100 & 10 & 0 & 0 \\
\hline 100 & 15 & 0 & 0 \\
\hline 100 & 20 & 0 & 0 \\
\hline 100 & 50 & 0 & 0 \\
\hline
\end{tabular}

$\mathrm{V}$ : Vinasse; $10 \mathrm{~mL} / \mathrm{L}=1 \%, 50 \mathrm{~mL} / \mathrm{L}=5 \%, 100 \mathrm{~mL} / \mathrm{L}=10 \%$

S: Sucrose; $0 \mathrm{~g} / \mathrm{L}=0 \%, 5 \mathrm{~g} / \mathrm{L}=0.5 \%, 10 \mathrm{~g} / \mathrm{L}=1 \%, 15 \mathrm{~g} / \mathrm{L}=1.5 \%, 20 \mathrm{~g} / \mathrm{L}=2 \%$, $50 \mathrm{~g} / \mathrm{L}=5 \%$

Y: Yeast extract; $0 \mathrm{~g} / \mathrm{L}=0 \%, 4 \mathrm{~g} / \mathrm{L}=0.4 \%$

${ }^{a}$ Number of bacterial strains that grew as ropy colonies on solid media within $48 \mathrm{~h}$ of incubation at $30^{\circ} \mathrm{C}$

5\%). All experiments were performed at $30^{\circ} \mathrm{C}$, which was reported as the optimum temperature for EPS production by Azotobacter spp. [49, 50]. After a 24-h incubation, only A. chroococcum 76A grew in the medium containing vinasse as the sole carbon source, and it produced the highest quantity of EPS $(25.3 \pm 0.10)$ in the medium containing $5 \%$ of sucrose after $48 \mathrm{~h}$ of incubation at $30{ }^{\circ} \mathrm{C}$ (Table 3). A. chroococcum 67B and AZ1 required 5\% of sucrose to grow, although lower EPS concentrations $(22.8 \pm 0.22$ and $21.5 \pm 0.26 \mathrm{mg} / 30 \mathrm{~mL}$, respectively) were detected (Table 3 ). $1 \%$ vinasse and $5 \%$ sucrose as carbon sources was the best substrate for stimulating the growth and metabolism of A. chroococcum 76A, 67B and AZ1. The ability of some strains belonging to the genus Azotobacter to synthesize EPS was widely recognized and reported [50-52] but $A$. chroococcum has been 
Table 3 Evaluation of EPS synthesis by different $A$. chroococcum strains in liquid media containing vinasse (1\%) without and with $2 \%$ or $5 \%$ of sucrose after $48 \mathrm{~h}$ of incubation at $30^{\circ} \mathrm{C}$

\begin{tabular}{|c|c|c|c|c|c|c|}
\hline \multirow[t]{2}{*}{ A. chroococcum strains } & \multicolumn{2}{|l|}{ V (1\%) } & \multicolumn{2}{|c|}{ V (1\%) S (2\%) } & \multicolumn{2}{|c|}{ V (1\%) S (5\%) } \\
\hline & Growth* & EPS $^{\S}$ & Growth* & EPS $^{\S}$ & Growth* & $\mathrm{EPS}^{\S, t}$ \\
\hline $76 \mathrm{~A}$ & + & -+ & + & -+ & + & $\begin{array}{l}+ \\
25.3 \pm 0.10^{a}\end{array}$ \\
\hline $67 \mathrm{~B}$ & - & - & - & - & + & $\begin{array}{l}+ \\
22.8 \pm 0.22^{b}\end{array}$ \\
\hline$A Z 1$ & - & - & - & - & + & $\stackrel{+}{21.5 \pm 0.26^{c}}$ \\
\hline
\end{tabular}

$V$ vinasse, $S$ sucrose

*bacterial growth: $-=$ absence of growth; $+=$ presence of growth (about $10^{8} \mathrm{CFU} / \mathrm{mL}$ )

$\S$ EPS synthesis: $-=$ no synthesis of EPS; $-+=$ low synthesis of EPS; $+=$ high synthesis of EPS

${ }^{\dagger} \mathrm{mg}$ of EPS/30 $\mathrm{mL}$ of medium. The values represent the mean \pm S.D. of three replicates of independent experiments. Different letters indicate significant difference $(P \leq 0.01)$

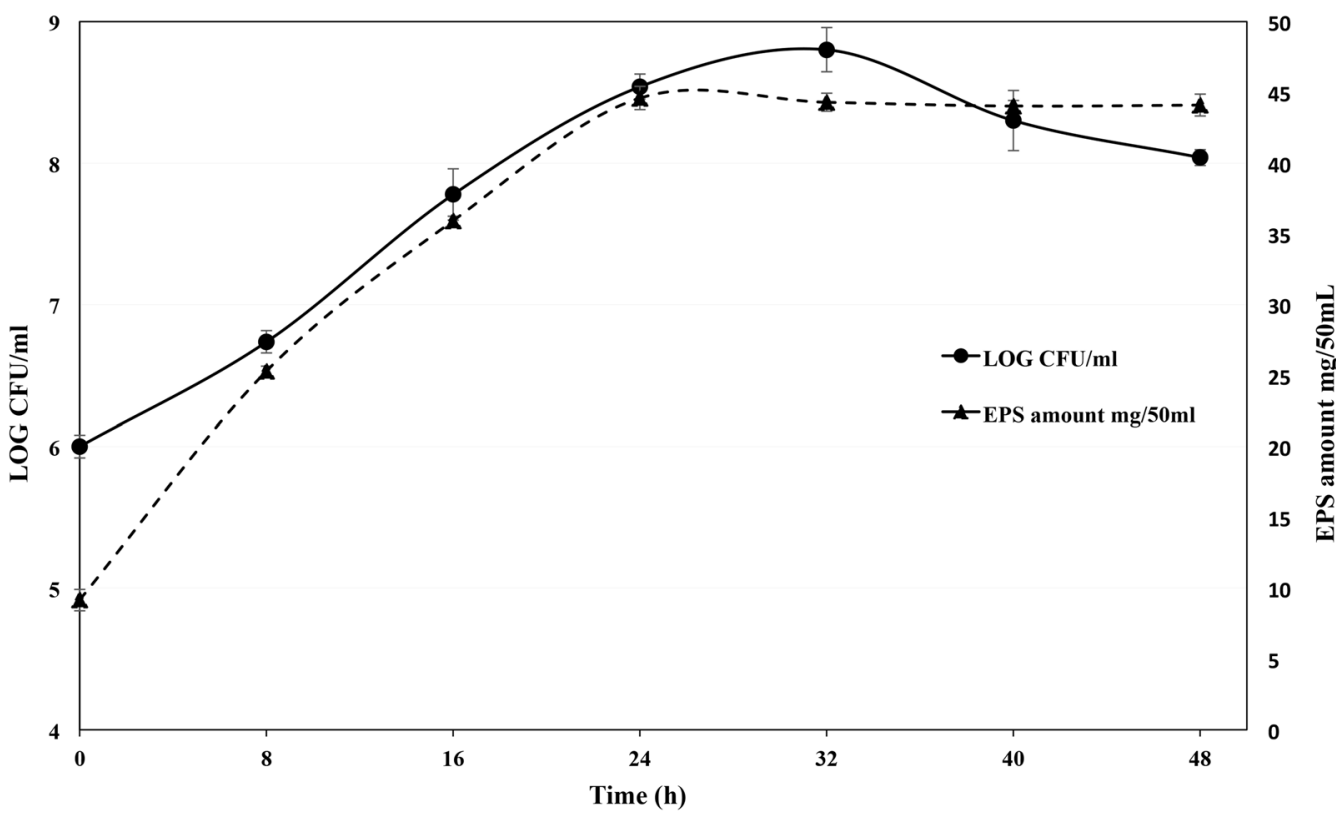

Fig. 2 Kinetics of cell growth and EPS synthesis by Azotobacter chroococcum $76 \mathrm{~A}$ grown for $48 \mathrm{~h}$ at $30^{\circ} \mathrm{C}$ in $50 \mathrm{~mL}$ of liquid medium containing $1 \%$ of vinasse and $5 \%$ of sucrose. Data are the mean of triplicates \pm S.D

extensively especially studied for its ability to promote plant growth under environmental stress conditions due to the synthesis of enzymes and EPS [53-55] but its ability to grow in medium containing vinasse was less investigated [56]. However, to our knowledge, this is the first study that explored the capacity of $A$. chroococcum to synthetize EPS utilizing vinasse as a carbon source. Quagliano and Iyazaki [57] tested the effect of different carbon sources on the production of EPS by A. chroococcum $6 \mathrm{~B}$. Using pure sugars, such as glucose and fructose, this strain was able to synthesize high amounts of EPS, with poly- $\beta$-hydroxybutyrate $(\mathrm{PHB})$ also detected when the strain was grown in the presence of glucose. Utilizing a complex carbon source such as sugarcane molasses, the concomitant production of EPS and PHB was observed [23]. The high amount of EPS obtained in this study using a complex carbon source could be due to the presence of fructose in the sugarcane vinasse. In fact, fructose, especially in nitrogen-limiting condition and an excess of carbon, promotes bacterial growth of diazotrophic bacteria [57], and therefore, EPS production since it is closely coupled with cell growth [58]. Moreover, fructose improves also EPS biosynthesis as fructose-6-phosphate is the first metabolite to be converted to mannose 6-phosphate in the pathway for alginate biosynthesis [57]. In addition, in stress conditions such as nitrogen limitation, Azotobacter 
spp. cultures grow under nitrogen fixation producing acidification of medium, that it is associated with EPS excretion [59].

Based on its biotechnological capabilities, A. chroococcum 76A was selected for further investigations. This strain was extensively characterized and previously selected and investigated as bio-effector in sustainable agricultural systems also under abiotic stressful conditions (drought and salinity) [53, 54]. Therefore, the growth and EPS production of A. chroococcum $76 \mathrm{~A}$ was monitored over a 48 -h incubation at $30{ }^{\circ} \mathrm{C}$ using medium containing $1 \%$ vinasse and $5 \%$ sucrose as carbon sources (Fig. 2). The maximum EPS concentration $(44.6 \pm 0.63 \mathrm{mg} / 50 \mathrm{~mL})$ was reached at $24 \mathrm{~h}$, corresponding to the sub-stationary growth phase $\left(7 \times 10^{8} \pm 0.29 \mathrm{CFU} / \mathrm{mL}\right)$, after which no significant differences in EPS synthesis were recorded (Fig. 2). Cell growth and EPS production kinetics by Paenibacillus jamilae were previously investigated by Morillo et al. [60]. According to our results, this strain reached the maximum production of EPS at the beginning of the stationary growth phase. However, Gauri et al. [50] reported that in $\mathrm{N}_{2}$-free basal glucose medium, the strain Azotobacter sp. SSB 81 reached the stationary phase after $36 \mathrm{~h}$, and the maximal amount of EPS produced was observed at $30 \mathrm{~h}$ in exponential phase growth, after which it suddenly decreased.

\section{Chemical characterization of EPS produced by $A$. chroococcum 76A}

The EPS produced by the selected strain A. chroococcum $76 \mathrm{~A}$ was recovered from solid or liquid media containing vinasse (1\%) and sucrose (5\%) after $24 \mathrm{~h}$ of incubation ay $30{ }^{\circ} \mathrm{C}$, to assess the gross chemical compositions by determining the total carbohydrate content, protein concentration and uronic acid content. As expected, carbohydrates were the dominant fraction, representing approximately 59 and $52 \%$ of the EPS synthetized by $A$. chroococcum 76A on solid and liquid medium, respectively (Table 4). However, the uronic acid content was approximately $23 \%(\mathrm{w} / \mathrm{w})$ in both samples, although the protein concentration appeared to be higher in EPS recovered from liquid cultures $(11.3 \pm 5.16 \%, \mathrm{w} / \mathrm{w})$ than

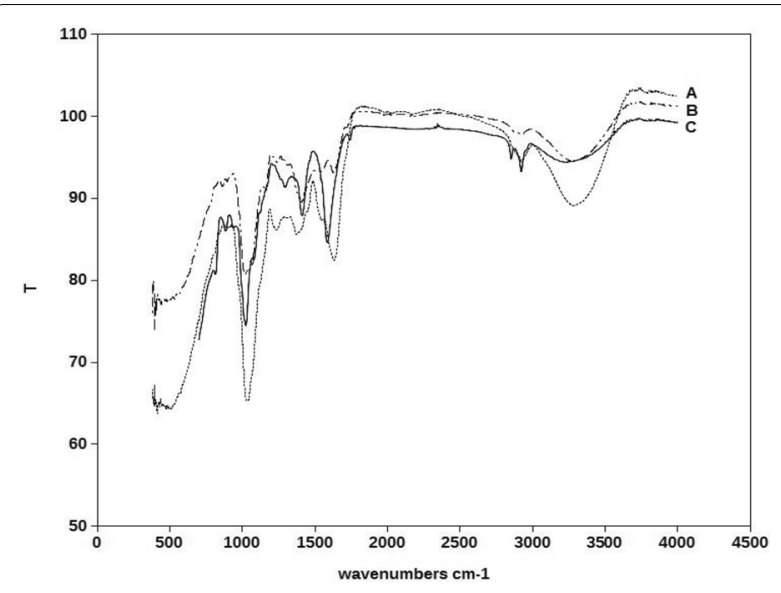

Fig. 3 FTIR-ATR analysis of EPS produced by Azotobacter chroococcum 76A on liquid (trace A) and solid (trace B) media containing vinasse (1\%) ad sucrose (5\%) as carbon sources, in comparison with alginate (trace $C$ )

from solid medium $(8.3 \pm 0.99 \%$, w/w; Table 4$)$. The monomer composition of both EPS samples showed that, in addition to uronic acids, the primary monosaccharide present was glucose (Table 4), suggesting that the isolated biopolymers were a complex mixture of polysaccharides. The heterogeneous composition of the EPSs can be ascribed to the different growth conditions, i.e. in liquid medium and on solid agar that were carried out respectively in the SB and SAB media, that are known to significantly affect the bacterial EPS's nature [61]. This result was also supported by FTIR-ATR and NMR spectral analyses. The IR spectra of EPS were reported in comparison with alginate. It was interesting to note the overlap of signals attributable to guluronic acid in both samples (Fig. 3). In particular, as shown in Fig. 3, the spectrum of the EPS recovered from either the liquid (trace A) or solid (trace B) media were characterized by a large signal at approximately $3300 \mathrm{~cm}^{-1}$, corresponding to the $\mathrm{O}-\mathrm{H}$ stretching vibrations of $\alpha$-carboxylic groups that are typical of uronic acids. Moreover, the primary signals observed at approximately $1724 \mathrm{~cm}^{-1}$ were particularly intense in the EPS recovered from liquid medium (Fig. 3, trace A), which could be attributed to the vibrations of

Table 4 Carbohydrate, protein and uronic acids contents in the EPS produced by Azotobacter chroococcum 76A grown on solid or in liquid media containing vinasse $(1 \%)$ ad sucrose $(5 \%)$ as carbon sources

\begin{tabular}{llll}
\hline Samples & Carbohydrate $(\%, w / w)$ & Protein (\%, w/w) & Uronic acids (\%, w/w) \\
\hline EPS agar ${ }^{a}$ & $58.3 \pm 1.62$ & $8.3 \pm 0.99$ & $22.7 \pm 2.61$ \\
EPS broth $^{b}$ & $52.0 \pm 2.12$ & $11.3 \pm 5.16$ & $22.8 \pm 3.76$ \\
\hline
\end{tabular}

\footnotetext{
a EPS produced by $A$. chroococcum $76 \mathrm{~A}$ after $24 \mathrm{~h}$ of growth on solid medium at $30^{\circ} \mathrm{C}$
}

b EPS produced by $A$. chroococcum $76 \mathrm{~A}$ after $24 \mathrm{~h}$ of growth in liquid medium at $30^{\circ} \mathrm{C}$ 


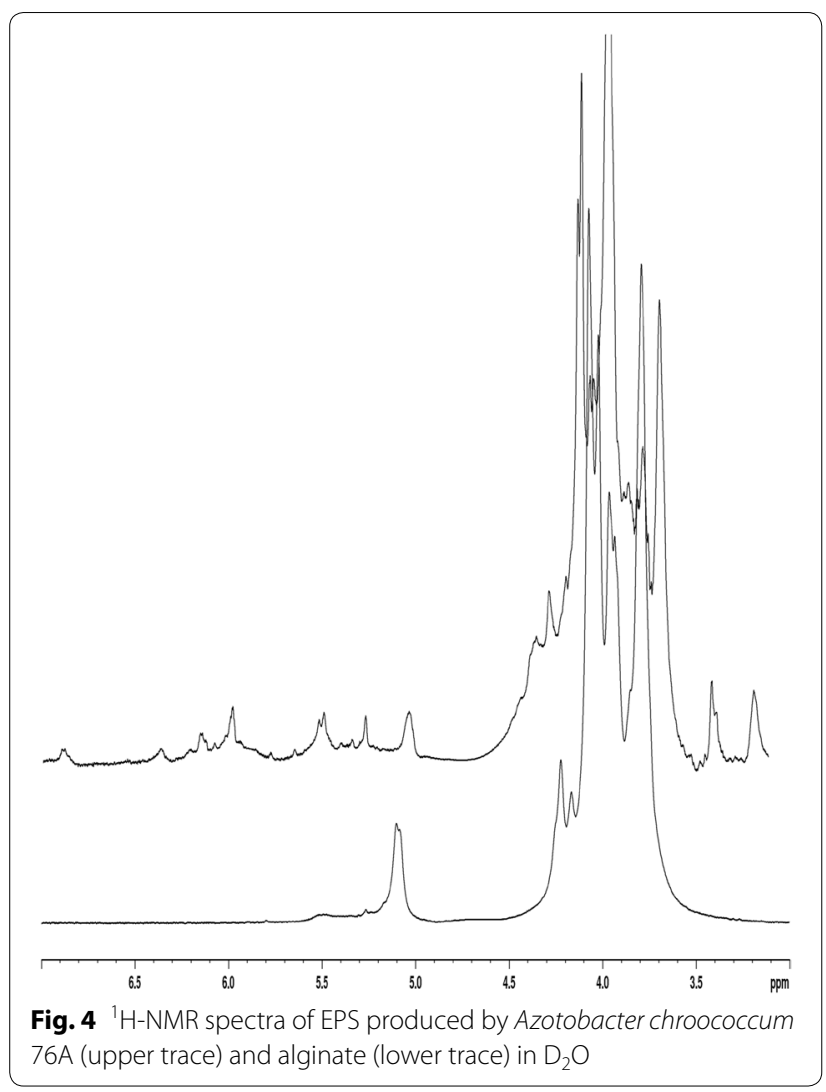

ester groups and symmetric and asymmetric stretching vibrations of guluronic acid, one of the two components of alginates (Fig. 3 , trace $\mathrm{C}$ ). The ${ }^{1} \mathrm{H}$-NMR spectrum analysis of the EPS also suggested that the isolated polymers were a mixture of different polysaccharides in which, in addition to an alginate fraction, a glucan fraction was also present as a primary component (Fig. 4). Indeed, in the anomeric region of the spectrum (from 4.3 to $5.9 \mathrm{ppm}$ ), the EPS synthetized on solid medium presented inter alia a primary signal at $5.19 \mathrm{ppm}$ (Fig. 4, upper trace) resembling the anomeric signals of alginate (Fig. 4, lower trace), in addition to other signals at approximately $5.46 \mathrm{ppm}$ that were attributable to glucose. A similar pattern of signals was seen in the EPS sample that was synthetized in liquid medium (data not shown). Alginates are polysaccharides composed of D-mannuronic and L-guluronic acids and are of great interest for a wide range of industrial applications, such as the pharmaceutical, agricultural, food, cosmetic, textile and paper industries as well as in water-treatment processes and cell immobilization and encapsulation [9, 62]. Moreover, some degradation products can be employed as anti-inflammatory and immunosuppressive agents in medical field [62]. Although most of the alginate currently produced for commercial purposes is derived from brown seaweeds
[63], considering the environmental concerns associated with marine algae harvesting and processing, there is increasing interest in alginates from bacteria, primarily due to their high purity and regular structure [64]. Bacterial alginate synthesis is restricted to bacteria belonging to the genera Pseudomonas and Azotobacter [65]. However, very few studies have investigated alginate produced by $A$. chroococcum despite the genus Azotobacter is considered the best candidate for the industrial production of alginate [66].

\section{Conclusions}

Microbial selection allowed the detection of $A$. chroococcum 76A, a new bacterial strain potential able of biobased alginate synthesis from cheap substrate containing vinasse. This approach represents a possible alternative to expensive disposal of agri-food wastes through their transformation into high value-added products.

\section{Abbreviations}

EPS: exopolysaccharide; SAB: Salts Agar Base; YM: Yeast Mannitol; SB: Salts Broth; PDM: polymer dry mass; FTIR-ATR: Attenuated Total Reflection Fourier Transform Infrared; ${ }^{1}$ H-NMR: Proton Nuclear Magnetic Resonance; PHA: polyhydroxyalkanoate; PHB: poly- $\beta$-hydroxybutyrate.

\section{Acknowledgements}

The authors thanks Agriges S.r.l. (San Salvatore Telesino, Benevento, Italy) that provided sugarcane vinasse used in this research.

\section{Authors' contributions}

W participated in the microbial selection and wrote the main manuscript text. BN, PDD and AP performed the chemical characterization of EPS and wrote the manuscript for this part. GP, VI and AR participated in the microbial selection and characterization of sugarcane vinasse. OP conceived the study, participated in its design, and revised the manuscript. All authors read and approved the final manuscript.

\section{Funding}

This work was supported by grant from the Ministero dell'Università e della Ricerca Scientifica Industrial Research Project "Development of green technologies for production of BIOchemicals and their use in preparation and industrial application of POLImeric materials from agricultural biomasses cultivated in a sustainable way in Campania region - BioPoliS"PON03PE_00107_1/1, funded in the frame of Operative National Programme Research and Competitiveness 2007-2013 D. D. Prot. n. 713/Ric. 29.10.2010.

Availability of data and materials

Not applicable.

\section{Ethics approval and consent to participate}

Not applicable.

\section{Consent for publication \\ Not applicable.}

\section{Competing interests}

The authors declare that they have no competing interests.

\section{Author details}

${ }^{1}$ Department of Agricultural Sciences, University of Naples Federico II, Via Università 100, 80055 Portici, NA, Italy. ${ }^{2}$ Institute of Biomolecular Chemistry, National Research Council of Italy, Via Campi Flegrei 34, 80078 Pozzuoli, NA, 
Italy. ${ }^{3}$ Department of Science and Technology, University of Naples Parthenope, Centro Direzionale, Isola C4, 80143 Naples, Italy.

\section{Received: 15 February 2019 Accepted: 20 May 2019} Published online: 23 August 2019

\section{References}

1. Ahmad NH, Mustafa S, Che Man YB. Microbial polysaccharides and their modification approaches: a review. Int J Food Prop. 2015;18:332-47.

2. Llamas I, Amjres H, Mata JA, Quesada E, Béjar V. The potential biotechnological applications of the exopolysaccharide produced by the halophilic bacterium Halomonas almeriensis. Molecules. 2012;17:7103-20.

3. Mata JA, Béjar V, Llamas I, Arias S, Bressollier P, Tallon R. Exopolysaccharides produced by the recently described halophilic bacteria Halomonas ventosae and Halomonas anticariensis. Res Microbiol. 2006;157:827-35.

4. Rühmann B, Schmid J, Sieber V. High throughput exopolysaccharide screening platform: from strain cultivation to monosaccharide composition and carbohydrate fingerprinting in one day. Carbohyd Polym. 2015;122:212-20.

5. Crescenzi V. Microbiol polysaccharides of applied interest. On going research activities in Europe. Biotech Prog. 1995;11:251-9.

6. Sutherland IW. Biotechnology of microbial exopolysaccharides. Cambridge: Cambridge University Press; 1990.

7. Sutherland IW. Novel and established applications of microbial polysaccharides. Trends Biotechnol. 1998;16:41-6.

8. Ventorino V, Sannino F, Piccolo A, Cafaro V, Carotenuto R, Pepe O. Methylobacterium populi VP2: plant growth-promoting bacterium isolated from a highly polluted environment for polycyclic aromatic hydrocarbon (PAH) biodegradation. Sci World J. 2014;2014:931793.

9. Kumar AS, Mody K. Microbial exopolysaccharides: variety and potential applications. In: Rehm BHA, editor. Microbial production biopolymers and polymer precursors - application and perspectives. Norfolk: Caister Academic Press; 2009. p. 229-53.

10. Kumar GC, Joo HS, Choi JW, Koo YM, Chang C-S. Purification and characterization of an extracellular polysaccharide from haloalkalophilic Bacillus sp. I-450. Enzyme Microb Tech. 2004;34:673-81.

11. Naspolini BF, Machado ACD, Cravo WB, Freire DMG, Cammarota MC Bioconversion of sugarcane vinasse into high-added value products and energy. Biomed Res Int. 2017;2017:8986165. https://doi. org/10.1155/2017/8986165.

12. Morris GA, Harding SE. Polysaccharides, microbial. In: Schaechter M, editor. Encyclopedia of microbiology. Amsterdam: Elsevier; 2009. p. 482-94.

13. Surayot U, Wang J, Seesuriyachan P, Kuntiya A, Tabarsa M, Lee YJ, Kim J-K, Parka WJ, You SG. Exopolysaccharides from lactic acid bacteria: structural analysis, molecular weight effect on immunomodulation. Int J Biol Macromol. 2014;68:233-40.

14. Thirugnanasambandham K, Sivakumar V, Prakash Maran J. Modeling and investigation of submerged fermentation process to produce extracellular polysaccharide using Lactobacillus confusus. Carbohydr Polym. 2014;114:43-7.

15. Kaur V, Bera MB, Panesar PS, Kumar H, Kennedy JF. Welan gum: microbial production, characterization, and applications. Int J Biol Macromol. 2014;65:454-61.

16. Palomba S, Cavella S, Torrieri E, Piccolo A, Mazzei P, Blaiotta G, Ventorino V, Pepe O. Polyphasic screening, homopolysaccharide composition, and viscoelastic behavior of wheat sourdough from a Leuconostoc lactis and Lactobacillus curvatus exopolysaccharide-producing starter culture. Appl Environ Microbiol. 2012;78:2737-47.

17. Pepe O, Ventorino V, Cavella S, Fagnano M, Brugno R. Prebiotic content of bread prepared with flour from immature wheat grain and selected dextran-producing Lactic Acid Bacteria. Appl Environ Microbiol. 2013;79:3779-85

18. Freitas F, Alves VD, Reis MAM. Advances in bacterial exopolysaccharides: from production to biotechnological applications. Trends Biotechnol. 2011;29:388-98.

19. Akram M, Tan CK, Garwood R, Thai SM. Vinasse - a potential biofuelcofiring with coal in a fluidised bed combustor. Fuel. 2015;158:1006-15.
20. Christofoletti CA Escher JP Correia JE Marinho JFU, Fontanetti CS Sugarcane vinasse: environmental implications of its use. Waste Manage. 2013:33:2752-61.

21. Montella S, Ventorino V, Lombard V, Henrissat B, Pepe O, Faraco V. Discovery of genes coding for carbohydrate-active enzyme by metagenomic analysis of lignocellulosic biomasses. Sci Rep. 2017;7:42623.

22. Pramanik A, Mitra A, Arumugam M, Bhattacharyya A, Sadhukhan S, Ray A, Haldar S, Mukhopadhyay UK, Mukherjee J. Utilization of vinasse for the production of polyhydroxybutyrate by Haloarcula marismortui. Folia Microbiol. 2012;57:71-9.

23. Pagliano G, Ventorino V, Panico A, Pepe O. Integrated systems for biopolymers and bioenergy production from organic waste and by-products: a review of microbial processes. Biotechnol Biofuels. 2017;10:113.

24. Pennacchio A, Ventorino V, Cimini D, Pepe O, Schiraldi C, Inverso M, Faraco $V$. Isolation of new cellulase and xylanase producing strains and application to lignocellulosic biomasses hydrolysis and succinic acid production. Bioresour Technol. 2018;259:325-33.

25. Cimini D, Argenzio O, D'Ambrosio S, Lama L, Finore I, Finamore R, Pepe O, Faraco V, Schiraldi C. Production of succinic acid from Basfia succiniciproducens up to the pilot scale from Arundo donax hydrolysate. Bioresour Technol. 2016;222:355-60.

26. Ventorino V, Robertiello A, Viscardi S, Ambrosanio A, Faraco V, Pepe O. Biobased chemical production from Arundo donax feedstock fermentation using Cosenzaea myxofaciens BPM1. BioResources. 2016;11:6566-81.

27. Ventorino V, Robertiello A, Cimini D, Argenzio O, Schiraldi C, Montella S, Faraco V, Ambrosanio A, Viscardi S, Pepe O. Bio-Based succinate production from Arundo donax hydrolysate with the new natural succinic acid-producing strain Basfia succiniciproducens BPP7. BioEnergy Res. 2017;10:488-98.

28. Moraes BS, Zaiat M, Bonomi A. Anaerobic digestion of vinasse from sugarcane ethanol production in Brazil: challenges and perspectives. Renew Sust Energ Rev. 2015;44:888-903.

29. Nogueira CEC, de Souza SNM, Micuanski VC, Azevedo RL. Exploring possibilities of energy insertion from vinasse biogas in the energy matrix of Panamá State, Brazil. Renew Sust Energ Rev. 2015;48:300-5.

30. Di Pasqua R, Ventorino V, Aliberti A, Robertiello A, Faraco V, Viscardi $S$, Pepe $O$. Influence of different lignocellulose sources on endo$1,4-\beta$-glucanase gene expression and enzymatic activity of Bacillus amyloliquefaciens B31C. BioResources. 2014;9:1303-10.

31. Pagliano G, Ventorino V, Panico A, Romano I, Robertiello A, Pirozzi F, Pepe $O$. The effect of bacterial and archaeal populations on anaerobic process fed with mozzarella cheese whey and buttermilk. J Environ Manage. 2018;217:110-22.

32. Ventorino V, Romano I, Pagliano G, Robertiello A, Pepe O. Pre-treatment and inoculum affect the microbial community structure and enhance the biogas reactor performance in a pilot-scale biodigestion of municipal solid waste. Waste Manage. 2018;73:69-77.

33. Sydney EB, Larroche C, Novak AC, Nouaille R, Sarma SJ, Brar SK, Letti LAJ, Soccol VT, Soccol CR. Economic process to produce biohydrogen and volatile fatty acids by a mixed culture using vinasse from sugarcane ethanol industry as nutrient source. Bioresour Technol. 2014;159:380-6.

34. Pagliano G, Ventorino V, Panico A, Romano I, Pirozzi F, Pepe O. Anaerobic process for bioenergy recovery from dairy waste: meta-analysis and enumeration of microbial community related to intermediates production. Front Microbiol. 2019;9:3229.

35. Ventorino V, Ionata E, Birolo L, Montella S, Marcolongo L, De Chiaro A, Espresso F, Faraco V, Pepe O. Lignocellulose-adapted endo-cellulase producing Streptomyces strains for bioconversion of cellulose-based materials. Front Microbiol. 2016;7:2061.

36. Ventorino V, Aliberti A, Faraco V, Robertiello A, Giacobbe S, Ercolini D, Amore A, Fagnano M, Pepe O. Exploring the microbiota dynamics related to vegetable biomasses degradation and study of lignocellulose-degrading bacteria for industrial biotechnological application. Sci Rep. 2015;5:8161.

37. Pepe $O$, Ventorino V, Blaiotta G. Dynamic of functional microbial groups during mesophilic composting of agro-industrial wastes and freeliving $\left(\mathrm{N}_{2}\right)$-fixing bacteria application. Waste Manage. 2013;33:1616-25.

38. Pepe O, Blaiotta G, Moschetti G, Greco T, Villani F. Rope-producing strains of Bacillus spp. from wheat bread and strategy for their control by lactic acid bacteria. Appl Environ Microbiol. 2003;69:2321-9. 
39. Palomba S, Blaiotta G, Ventorino V, Saccone A, Pepe O. Microbial characterization of sourdough for sweet baked products in the Campania region (southern Italy) by a polyphasic approach. Ann Microbiol. 2011;61:307-14.

40. Parillo R, Ventorino V, Pepe O, Rivas PC, Testa A. Use of compost from chestnut lignocellulosic residues as substrate for tomato growth. Waste Biomass Valoriz. 2017;8:2711-20.

41. Dubois M, Gilles KA, Hamilton JK, Rebers PA, Smith F. Colorimetric method for determination of sugars and related substances. Anal Chem. 1956;28:350-6.

42. Bradford MM. A rapid and sensitive method for the quantification of microgram quantities of protein utilizing the principle of protein-dye binding. Anal Biochem. 1976;72:248-54.

43. Blumenkrantz N, Asboe-Hansen G. New method for quantitative determination of uronic acids. Anal Biochem. 1973;54:484-9.

44. Finore I, Poli A, Di Donato P, Lama L, Trincone A, Fagnano M, Mori M, Nicolaus B, Tramice A. The hemicellulose extract from Cynara cardunculus: a source of value-added biomolecules produced by xylanolytic thermozymes. Green Chem. 2016;18:2460-72.

45. Yildiz SY, Anzelmo G, Ozer T, Radchenkova N, Genc S, Di Donato P, Nicolaus B, Oner ET, Kambourova M. Brevibacillus themoruber: a promising microbial cell factory for exopolysaccharide production. J Appl Microbiol. 2014;116:314-24.

46. Søborg DA, Hendriksen NB, Kilian M, Kroer N. Widespread occurrence of bacterial human virulence determinants in soil and freshwater environments. Appl Environ Microbiol. 2013;79:5488-97.

47. Palmqvist $E_{1}$ Hahn-Hägerdal B. Fermentation of lignocellulosic hydrolysates. I: inhibition and detoxification. Bioresour Technol. 2000;74:17-24.

48. Vermani MV, Kelkar SM, Kamat MY. Studies in polysaccharide production and growth of Azotobacter vinelandii MTCC 2460, a plant rhizosphere isolate. Lett Appl Microbiol. 1997;24:379-83.

49. Dhanasekar R, Viruthagiri T, Sabarathinam PL. Poly(3-hydroxy butyrate) synthesis from a mutant strain Azotobacter vinelandii utilizing glucose in a batch reactor. Biochem Eng J. 2003;16:1-8.

50. Gauri SS, Mandal SM, Mondal KC, Dey S, Pati BR. Enhanced production and partial characterization of an extracellular polysaccharide of a newly isolated Azotobacter SSB81. Bioresour Technol. 2009;100:4240-3.

51. Gauri SS, Mandal SM, Pati BR. Impact of Azotobacter exopolysaccharides on sustainable agriculture. Appl Microbiol Biotechnol. 2012;95:331-8.

52. Vargas-Garcia MC, Lopez MJ, Elorrieta MA, Suarez J, Moreno J. Properties of polysaccharide produced by Azotobacter vinelandii cultured on 4-hydroxybenzoic acid. J Appl Microbiol. 2003;94:388-95.

53. Van Oosten MJ, Di Stasio E, Cirillo V, Silletti S, Ventorino V, Pepe O, Raimondi G, Maggio A. Root inoculation with Azotobacter chroococcum 76A enhances tomato plants adaptation to salt stress under low $\mathrm{N}$ conditions. BMC Plant Biol. 2018;18:205.

54. Viscardi S, Ventorino V, Duran P, Maggio A, De Pascale S, Mora ML, Pepe O. Assessment of plant growth promoting activities and abiotic stress tolerance of Azotobacter chroococcum strains for a potential use in sustainable agriculture. J Soil Sci Plant Nutr. 2016;16:848-63.
55. Woo SL, Pepe O. Microbial consortia: promising probiotics as plant biostimulants for sustainable agriculture. Front Plant Sci. 2018;9:1801.

56. Omar MNA, Mostafa AT, Ahmed AS. Concentrated vinasse as a novel diazotrophs growth medium (biovinasse inoculant) and soil conditioner to improve faba bean yield under dripping irrigation system. In: Symposium No. 3, Paper No. 137, 17th WCSS, Thailand; 2002. p. 14-21.

57. Quagliano JC, Iyazaki SS. Biosynthesis of poly-beta-hydroxybutyrate and exopolysaccharides on Azotobacter chroococcum strain 6B utilizing simple and complex carbon sources. Appl Biochem Biotechnol. 1999;82:199-208

58. Wang J, Yu H. Biosynthesis of polyhydroxybutyrate (PHB) and extracellular polymeric substances (EPS) by Ralstonia eutropha ATCC 17699 in batch cultures. Appl Microbiol Biotechnol. 2007;75:871-8.

59. Vermani MV, Kelkar SM, Kamat MY. Production and optimization of certain growth parameters for an exopolysaccharide from Azotobacter vinelandii MTCC 2460 isolated from a plant rhizosphere. J Ferment Bioeng. 1995;80:599-602.

60. Morillo JA, del Aguila VG, Aguilera M, Ramos-Cormenzana A, MonteolivaSanchez M. Production and characterization of the exopolysaccharide produced by Paenibacillus jamilae grown on olive mill-waste waters. World J Microbiol Biotechnol. 2007;23:1705-10.

61. Sengupta D, Datta S, Biswas D. Towards a better production of bacterial exopolysaccharides by controlling genetic as well as physico-chemical parameters. Appl Microbiol Biotechnol. 2018;102:1587-98.

62. Remminghost $\mathrm{U}$, Rehm BH. Microbial production of alginate: biosynthesis and applications. In: Rehm BHA, editor. Microbial production of byopolimers and polymer precursors: application and perspective. Norfolk: Caister Academic Press; 2009. p. 13-42.

63. Hoefer D, Schnepf JK, Hammer TR, Fischer M, Marquardt C. Biotechnologically produced microbial alginate dressings show enhanced gel forming capacity compared to commercial alginate dressings of marine origin. J Mater Sci Mater Med. 2015;26:162.

64. Sabra W, Zeng A-P, Deckwer W-D. Bacterial alginate: physiology, product quality and process aspects. Appl Microbiol Biotechnol. 2001;56:315-25.

65. Draget KI, Moe ST, Skjåk-Bræk G, Smidsrød O. Alginates. In: Stephen AM, Phillips GO, Williams PA, editors. Food polysaccharides and their applications. 2nd ed. Boca Raton: CRC Press; 2006. p. 289-334.

66. Pandurangan G, Subbiah J, Thiyagarajan K, David JK. Small scale production and characterization of alginate from Azotobacter chroococcum using different substrates under various stress conditions. Int J Appl Biol Pharm Technol. 2012;3:40-5.

\section{Publisher's Note}

Springer Nature remains neutral with regard to jurisdictional claims in published maps and institutional affiliations.

\section{Submit your manuscript to a SpringerOpen ${ }^{\circ}$ journal and benefit from:}

- Convenient online submission

- Rigorous peer review

- Open access: articles freely available online

- High visibility within the field

- Retaining the copyright to your article

Submit your next manuscript at $\boldsymbol{\Delta}$ springeropen.com 